\title{
KOMBINASI TRAY AERATOR DAN FILTRASI UNTUK MENURUNKAN KADAR BESI (FE) DAN MANGAN (MN) PADA AIR SUMUR
}

\author{
Muhammad Al Kholif *, Sugito, Pungut, dan Joko Sutrisno \\ Program Studi Teknik Lingkungan, Fakultas Teknik Sipil dan Perencanaan, Universitas PGRI Adi Buana \\ Surabaya \\ *E-mail: alkholif87@unipasby.ac.id
}

\section{ABSTRACT \\ COMBINATION OF TRAY AERATOR AND FILTRATION TO REDUCING IRON (FE) AND MANGANESE (MN) LEVELS IN WATER WELLS}

The problem that is often found in water well is the high content of iron $(\mathrm{Fe})$ and manganese (Mn). This study aims to reduce the content of Fe and $\mathrm{Mn}$ in water well with aeration and filtration systems. Aeration used is a multilevel aerator tray using 4 tray trays which are spaced $30 \mathrm{~cm}$ between the trays. The filtration media used are activated carbon and zeolite sand with a height of $70 \mathrm{~cm}$ each. The sample was taken at one of the community wells in the Dukuh Menanggal area of Sidoarjo. The study was conducted for 7 days with a processed sampling system carried out on the aerator tray output and both filtration. The results showed that the aeration process with tray aerator was able to reduce Fe levels up to $98.34 \%$ and Mn reached $97.40 \%$. In the filtration process with activated carbon can reduce Fe levels by $98.48 \%$ and $\mathrm{Mn}$ by $98.25 \%$. While the filtration process with zeolite sand media can reduce Fe levels by $98.43 \%$ and Mn by $97.44 \%$

Keywords: Aeration; Filtration; Tray Aerator; Water Wells

\section{PENDAHULUAN}

Air sumur adalah sumber air bersih yang sering kali pakai masyrakat dalam skala besar. Permasalahan yang sering timbul dari air tanah adalah tingginya kadar pencemar yang terkandung di dalamnya. Jika dilihat dari standar yang ditetapkan, maka air yang layak untuk digunakan tentunya disesuaikan dengan persyaratan yang ada. Jika dari persyaratan yang ada belum terpenuhi, menandakan hal tersebut tidak dapat dipergunakan sebagai kebutuhan air bersih. Permasalahan lain yang sering muncul dari penggunaan air tanha atau sumur adalah tingginya kandungan Besi $(\mathrm{Fe})$ dan Mangan (Mn). Kedua kandungan tersebut mudah larut dalam air dan keberadaannya sangat sulit untuk dideteksi dengan mata telanjang (Purwono \& Karbito, 2013).
Kualitas air tanah dipengaruhi kandungan mineral dan bahan-bahan lainnya. Mineral dalam air tanah ditemukan berbagai unsur kimia yang terdapat di dalam air tanah. Keberadaan berbagai mineral sebagiannya diperlukan oleh tubuh namun ada sebagian yang tidak dibutuhkan oleh tubuh manusia bahkan dapat mengganggu kesehatan manusia. Air dapat memberikan manfaat yang optimal jika memenuhi syarat kesehatan yang ditetapkan oleh World Health Organization (WHO) (Azkiyah \& Sutrisno, 2014). Ketersediaan air bersih adalah suatu problematika global yang harus secepatnya diselesaikan (Astuti et al., 2007).

Tingginya zat pencemar seperti $\mathrm{Zn}$ dan Mn pada air bukan lagi merupakan sesautu hal yang baru. Warna air yang berubah setalah terjadinya kontak dengan udara dalam 
waktu tertentu menandakan adanya kadar $\mathrm{Fe}$ dan Mn yang tinggi dalam air. Hal yang paling mudah untuk mendeteksi keberadaan kedua kadar tersebut dalam air adalah dengan mengamati kondisi bau, dan timbul warna kekuning-kuningan pada bak dan pakaian (Rasman \& Saleh, 2016). Upaya untuk mengatasi itu adalah dirancanglah alat untuk mengolah air sumur dijadikan air bersih.

Di Indonesia khususnya di wilayah perkotaan, penyediaan air bersih dalam skala besar masih di kelola oleh Perusahaan Air Minum (PAM). Sebagian besar pelayanan air bersih belum mendapatkan hasil yang maksimal atau jumlahnya belum mencukupi untuk pelayanan masyarakat baik dalam segi kualitas maupun kuantitas. Wilayah yang tidak terjaringi oleh air bersih pada akhirnya memilih untuk memanfaatkan air tanah (sumur) atau sumber mata air lainnya untuk kebutuhan air bersih. Persentase masyarakat yang menggunakan air tanah di Indonesia sangat tinggi karena murah dan mudah diperoleh. Dari data statistik menunjukan bahwa masyarakat yang memakai air leding sebesar $16,08 \%$, air tanah sebesar $11,61 \%$, air sumur (perigi) yaitu 49,92\%, mata air sebesar $13,92 \%$, air sungai yaitu $4,91 \%$, air hujan sebesar 2,62\% dan lainnya sebesar 0,80\% (Purwono \& Karbito, 2013).

Dalam beberapa kasus seperi pada PAM masih sering dijumpai endapan $\mathrm{Fe}$ dan $\mathrm{Mn}$ dalam jumlah yang kecil. Penggunaan media zeolit serta karbon aktif sebagai media media keramik ganda dalam filter mampu mereduksi senyawa $\mathrm{Fe}$ dan $\mathrm{Mn}$ pada air bersih (Mifbakhuddin et al., 2008; Nurhasmi et al., 2015). Kadar Fe dan Mn dalam air juga dapar direduksi dengan menggunakan radiasi ultraviolet. Penggunaan radiasi ultraviolet juga dapat menginaktivasi mikroorganisme dalam air bersih (Rezagama, 2013; Wahyudin et al., 2013). Di Kabupaten Gowa, mayoritas masyarakat kota nya memperoleh air bersih yang bersumber dari air sumur gali dengan kedalaman air rata-rata mencapai 7-10 meter. Mulai dari komunitas kecil sampai pada komunitas individu sebagian besar masyarakatnya mengambil air tanah sebagai kebutuhan air minum (Ronny \& Hasim, 2018).
Jika konsentrasi zat $\mathrm{Fe}$ melebihi 5 $\mathrm{mg} / \mathrm{L}$, maka penggabungan dua teknologi sekaligus yaitu teknologi aerasi-filtrasi dapat dijadikan sebagai acuan dalam mereduksi zat Fe tersebut (Muliawan \& Ilmianih, 2016). Partikel-partikel hasil pengendapan dari proses aerasi yang memiliki masa jenis hampir sama dengan air akan sukar untuk mengendap sendirinya, maka dari itu perlu adanya proses penyaringan atau filtrasi terhadap partikel-partikel tersebut. Metode filtrasi saat ini telah banyak mengalami modifikasi diantaranya dengan mengkombinasikan arah aliran dan media filtrasi. Bahan-bahan yang biasa digunakan sebagai media filtrasi diantaranaya seperti karbon aktif, zeolite dan pasir (Febiary et al., 2016). Pada penelitian yang dilakukan oleh (Saifudin \& Astuti, 2005) didapatkan efektifitas penggabungan teknologi dalam mengurangi kadar $\mathrm{Fe}$ dan $\mathrm{Mn}$ yaitu menggunakan pasir dan zeolite yaitu mencapai 93,52\%.

Permasalahan yang muncul untuk dijadikan obyek penelitian adalah banyaknya masyarakat yang tidak mengetahui kalau air sumur yang mereka gunakan banyak mengandung $\mathrm{Fe}$ dan $\mathrm{Mn}$ yang tidak memenuhi persyaratan yang telah ditetapkan. Penelitian ini akan mengkombinasikan suatu pengoalahan air sumur dengan menerapkan sistem tray aerator dengan filter dalam mereduksi kadar $\mathrm{Fe}$ dan $\mathrm{Mn}$ pada air sumur warga di daerah Dukuh Menanggal Surabaya. Tujuan utama dari penelitian ini adalah mengkaji setiap perubahan yang terjadi pada kadar $\mathrm{Fe}$ dan $\mathrm{Mn}$ setelah dilakukan pengolahan dengan menerapkan tray aerator dan filtrasi. Dari hasil penetian menunjukan adanya perubahan kadar Fe dan Mn pada air tanah setalah dilakukan pengolahan dengan menggunakan tray aerator dan filtrasi.

\section{METODOLOGI}

Alat penelitian dirancang dalam skala laboratorium mengacu pada unit PAM yang sesungguhnya dengan mengkombinasikan dua teknologi sekaligus untuk mereduksi zat $\mathrm{Fe}$ dan Mn pada air sumur. Sampel air sumur diperoleh dari salah satu warga di daerah Dukuh Menanggal Surabaya. Aerasi yang 
digunakan adalah Tray Aerator sedangkan filtrasi yang digunakan adalah media zeolit dan karbon aktif.

Tray aerator yang diaplikasikan pada penelitian ini adalah ketinggian mencapai 180 $\mathrm{cm}$ dengan variasi jumlah nampan yaitu sebanyak 4 nampan (tray). Masing-masing tray berjarang $30 \mathrm{~cm}$. Filtrasi yang digunakan dalam peneltian ini yaitu terbuat dari pipa akrilik berdiameter $20 \mathrm{~cm}$. Ketinggian tabung filtrasi yaitu mencapai $1 \mathrm{~m}$ dengan rancangan ketingian media yang sama yaitu mencapai 70 $\mathrm{cm}$. penelitian dilakukan selama 7 hari untuk melihat setiap perubahan yang terjadi antara pengolahan tray aerator dan filtrasi. Penelitian dilakukan dengan sistem batch sehingga tidak membutuhkan debit aliran dalam mengambil air hasil olahan. Secara garis besar gambar reaktor pengolahan tersaji pada Gambar 1. Reaktor pengolahan merupakakan sebagaian besar rangkaian perpipaan dengan menggunakan sistemm aliran down flow.

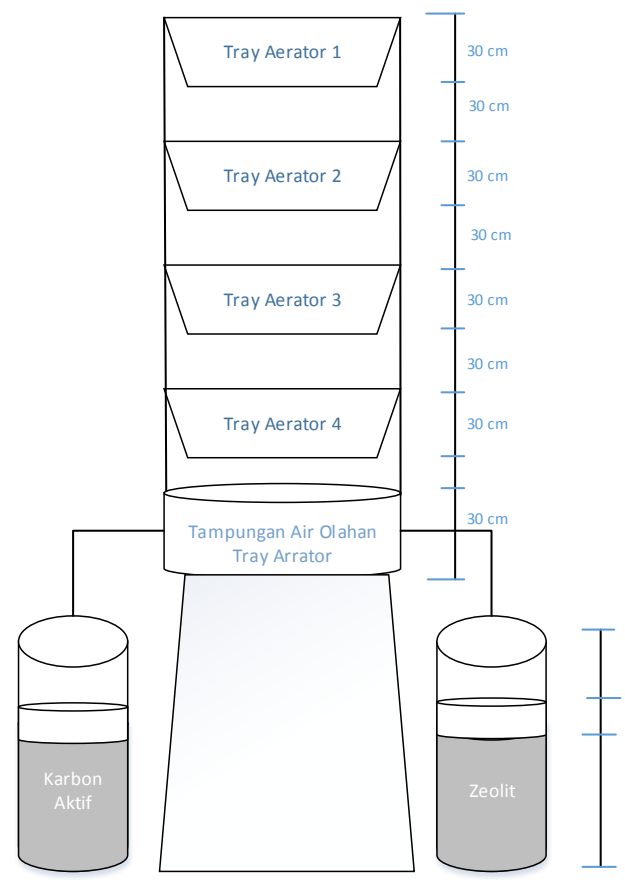

Gambar 1. Rangkaian Alat Pengolahan Air Sumur

Gambar 1 menjelaskan bahwa sampel air sumur terlebih dahulu di tamping pada sebuah wadah inlet setelah dipompa dari sumber sampel. Dari wadah inlet tersebut kemudian air dialirkan menuju tray aerator yang terdiri dari 4 susunan tray aerator.
Tujuan utama dari tray aerator tersebut adalah untuk menggontakkan air dengan udara sehingga terdapat kandungan oksigen di dalam air. Hasil olahan pada tray aerator ditampung pada sebuah wadah olahan. Hasil olahan tersebut kemudian diaambil untuk dianalisis kadar Fe dan Mn nya. Selain itu dari hasil oalahan tray aerator tersebut juga di alirkan secara down flow ke kedua alat filter yang sudah dilengkapi dengan media filter yaitu karbon aktif dan zeolit. Pengambilan sampel olahan yang berada di dalam filter dilakukan secara manual karena menggunakan sistem batch. Untuk dianalisis di laboratorium sampel didiamkan bersama media filter terlebih dahulu selama 24 jam dengan tujuan agar media filter dapat bekerja secara maksimal dalam mereduksi kadar Fe dan Mn dalam air.

Metode analisis data yang akan diterapkan yakni masing-masing sampel yang didapatkan dari hasil pemeriksaan laboratorium akan dikumpulkan. Setelah data terkumpul, maka selanjutnya akan dilakuakan analisis data yang akan disajikan dalam bentuk tabel kemudian akan di uraiakan dalam bentuk narasi dan ditarik suatu kesimpulan. Data tersebut dianalisa meliputi efektifitas penurunan parameter $\mathrm{Fe}$ dan $\mathrm{Mn}$ pada air sumur dengan menerapkan persamaan sebagai berikut.

$$
\text { Efektifitas }(\%)=\frac{(\mathrm{a}-\mathrm{b})}{\mathrm{a}} \times 100 \%
$$

Dimana: $a=$ nilai Awal

$$
\mathrm{b}=\text { nilai Akhir }
$$

\section{HASIL DAN PEMBAHASAN}

Penelitian dilakukan dengan mengecek terlebih dahulu karakteristik awal dari air sumur gali sebelum dilakukan pengolahan dengan menggunkan tray aerator dan filtrasi. Hasil dari karakteristik awal ini dapat dijadikan acuan untuk mengetahui seberapa besar efisiensi dari unit pengolahan air yang digunakan. Dari hasil pengamatan di lapangan menunjukan bahwa 90\% lebih warga Desa Bungurasih Kecamatan Waru menggunakan air sumur sebagai kebutuhan air bersih. Masyarakat tidak menyadari adanya potensi 
bahaya yang besar dari penggunaan air yang diperoleh dari sumur gali tersebut. Berdasarkan hasil pengukuran awal di laboratorium menunjukan kadar awal Fe yaitu 1,68 mg/l dan kadar Mn yakni 1,14 mg/l.

\subsection{Efisiensi Penurunan Kadar Fe dan Mn pada Aerasi Tray Aerator}

Langkah penting yang harus dilakukan untuk meningkatkan efektifitas proses pengolahan air adalah dengan melakukan penyaringan. Penyaringan dapat dialkuan dengan berbagai cara. Hal yang paling sederhana tentunya dengan menggunakan kain sebagai penyaring kotoran menurunkan padatan tersuspensi dan larva dalam air (Herlambang, 2010). Penggunaan desinfeksi pada pengolahan air diyakini dapat menurunkan kadar $\mathrm{Fe}$ dan $\mathrm{Mn}$. Pada penerapan desinfeksi ozon dengan konsentrasi sebesar $0,576 \mathrm{mg} / \mathrm{L}$ air dengan waktu kontak 60 menit memberikan pengaruh yang besar terhadap perubahan kadar $\mathrm{Fe}$ dan $\mathrm{Mn}$ dalam air. Dengan waktu kontak selama 60 menit dapat menurunkan kadar $\mathrm{Fe}$ sebesar 0,045 $\mathrm{mg} / \mathrm{L}$ dan $\mathrm{Mn}$ sebesar 0,004 mg/L (Wahyudin et al., 2013).

Penelitian lain yang dilakukan secara rinci dengan menggunakan metode aerasi kaskade menunjukan bahwa air dapat memerangkap oksigen saat menuruni tangga sehingga terjadi peningkatan kadar oksigen dalam air. Aerasi kaskade digunakan pada kondisi aerasi yang memadai atau sesuai yaitu pada area di bidang sungai, kanal, pembenihan ikan tambak, instalasi pengolahan air, dan lain-lain (Baylar et al., 2007). Berikut efisiensi penurunan kadar Fe dan Mn pada aerasi tray aerator yang di tunjukan pada tabel 1 dan 2 .

Tabel 1. Hasil Pengukuran Kadar Fe pada Tray Aerator

\begin{tabular}{ccccc}
\hline Hari & Awal $(\mathbf{m g} / \mathbf{l})$ & Akhir $(\mathbf{m g} / \mathbf{l})$ & Penurunan $(\mathbf{m g} / \mathbf{l})$ & Efisiensi \\
\hline 1 & 1,68 & $0,298 \times 10^{-2}$ & 1,6502 & $98,22 \%$ \\
2 & 1,68 & $0,298 \times 10^{-2}$ & 1,6502 & $98,22 \%$ \\
3 & 1,68 & $0,295 \times 10^{-2}$ & 1,6505 & $98,25 \%$ \\
4 & 1,68 & $0,294 \times 10^{-2}$ & 1,6506 & $98,25 \%$ \\
5 & 1,68 & $0,285 \times 10^{-2}$ & 1,6515 & $98,30 \%$ \\
6 & 1,68 & $0,280 \times 10^{-2}$ & 1,6520 & $98,33 \%$ \\
7 & 1,68 & $0,278 \times 10^{-2}$ & 1,6522 & $98.34 \%$ \\
\hline
\end{tabular}

Tabel 2. Hasil Pengukuran Kadar Mn pada Tray Aerator

\begin{tabular}{ccccc}
\hline Hari & Awal (mg/l) & Akhir (mg/l) & Penurunan (mg/l) & Efisiensi \\
\hline 1 & 1,14 & $0,299 \times 10^{-2}$ & 1,1101 & $97,37 \%$ \\
2 & 1,14 & $0,298 \times 10^{-2}$ & 1,1102 & $97,38 \%$ \\
3 & 1,14 & $0,297 \times 10^{-2}$ & 1,1103 & $97,39 \%$ \\
4 & 1,14 & $0,297 \times 10^{-2}$ & 1,1103 & $97,39 \%$ \\
5 & 1,14 & $0,298 \times 10^{-2}$ & 1,1102 & $97,38 \%$ \\
6 & 1,14 & $0,297 \times 10^{-2}$ & 1,1103 & $97,39 \%$ \\
7 & 1,14 & $0,296 \times 10^{-2}$ & 1,1104 & $97,40 \%$ \\
\hline
\end{tabular}

Tabel 1 dan 2 menunjukan adanya penurunan yang terjadi pada kadar Fe dan Mn setelah dilakukan pengolahan air sumur dengan sistem tray aerator. Secara keseluruhan untuk ke dua jenis parameter olahan memiliki nilai efisiensi lebih dari $95 \%$. Pada kadar Fe dari sampel awal sebesar 1,68 $\mathrm{mg} / \mathrm{L}$ turun rata-rata menjadi ini $1,65 \mathrm{mg} / \mathrm{L}$.
Nilai efisiensi penurunan tertinggi untuk parameter Fe mencapai $98,34 \%$ pada hari ke7 penelitian. Sedangkan pada kadar Mn efisiensi penyisihan terbaik pada hari terakhir penelitian yakni mencapai $97,40 \%$. Nilai awal kadar Mn jauh lebih kecil jika dibandingkan dengan kadar awal pada kadar Fe. Terjadinya penurunan kadar besi pada aerasi tray aerator 
karena adanya kontak antara air dengan udara yang membentuk endapan $\mathrm{Fe}\left(\mathrm{OH}_{3}\right)$ (Joko \& Rachmawati, 2016). Hasil di atas menunjukan terjadi penurunan sesuai dengan reaksi aerasi seperti:

$$
4 \mathrm{Fe}^{2+}+\mathrm{O}_{2}+10 \mathrm{H}_{2} \mathrm{O} \rightarrow 4 \mathrm{Fe}(\mathrm{OH})_{3}+8 \mathrm{H}^{+}
$$

Tray aerator dengan variasi 2 tray memiliki efisiensi penurunannya kadar $\mathrm{Fe}$ hanya mencapai 10\% (Lutfihani \& Purnomo, 2015). Sedangkan penerapan tray aerator dengan variasi 3 tray memiliki efisiensi penurunan kadar $\mathrm{Fe}$ mencapai $52 \%$ (Nainggolan et al., 2017). Hal ini menujukan adanya perbedaan dengan penelitian sekarang jika dilihat dari efisiensi penurunan penelitian, dimana pada penelitian sekarang yang menggunakan 4 tray memiliki efisiensi lebih baik. Banyaknya jumlah tray pada pada aerator sangat berpengaruh pada hasil aerasi. Selain itu juga akan memberikan kontak yang lama antara oksigen dengan air sehingga kadar Fe dapat teroksidasi dengan baik (Joko \& Rachmawati, 2016).

Penurunan kadar Mn pada tray aerator juga dipengaruhi karena adanya transfer oksigen ke dalam air. Proses aerasi juga dapat mereduksi bahan organik yang mudah menguap. Terjadinya kontak langsung antara sampel dan gas mengakibatkan adanya perpindahan senyawa seperti pada reaksi berikut:

$$
2 \mathrm{Mn}^{2+}+\mathrm{O}_{2}+2 \mathrm{H}_{2} \mathrm{O} \rightarrow 2 \mathrm{MnO}_{2}+4 \mathrm{H}^{+}
$$

Metode aerasi dengan menggunakan 5 buah tray aerator menunjukan hasil yang efektif tertutama pada kadar Fe. Nilai rata-rata penurunan kadar $\mathrm{Fe}$ setelah dilakukan pengolahan dengan menggunakan 5 buah tray aerator diperoleh hasil sebesar $1,12 \mathrm{mg} / \mathrm{L}$. Hal ini masih di luar batas maksimum yang disyaratkan oleh Menteri Kesehatan Republik Indonesia yang mensyaratkan besar kadar $\mathrm{Fe}$ yang diperbolehkan yaitu sebesar $1,00 \mathrm{mg} / \mathrm{L}$ (Ronny \& Hasim, 2018). Jumlah penampang akan mempengaruhi injeksi udara dengan sampel air pada proses aerasi (Lutfihani \& Purnomo, 2015).

\subsection{Efisiensi removal Kadar Fe dan Mn pada Reaktor Filtrasi Bermedia Karbon Aktif}

Perbedaan debit aliran dalam sistem pengolahan menunjukan hasil yang berbeda. Pada debit $0,5 \mathrm{~L} /$ menit terjadi penurunan $\mathrm{Fe}$ sebesar 11,7\% sedangkan Mn sebesar 23.3\%. pada debit aliran 1,0 L/menit mampu menurunkan kadar Fe dan Mn sebesar 28,6\% dan pada debit aliran 2,0 L/menit mampu menurunkan kadar $\mathrm{Fe}$ sebesar 30,4\% dan kadar Mn turun menjadi 29,1\% (Purwono \& Karbito, 2013).

Karbon aktif meruapakan bahan yang mampu menyerap kadar logam terutama kadar logam dalam air (Nurhasmi et al., 2015). Karbon aktif memiliki struktur amorf atau mikrokristalin dengan luas permukaan yang tinggi yaitu sekitar $1500 \mathrm{~m}^{2} / \mathrm{g}$ serta mempunyai daya serap dalam fase cair maupun fase gas (Cobb et al., 2012). Banyak bahan yang bisa digunakan sebagai sumber karbon aktif, namun yang sering digunakan untuk mengolaha air adalah karbon aktif yang terbuat dari batok kelapa. Hal ini karena batok kelapa memiliki miktopori yang banyak, kadar abu yang rendah dan memiliki sifat kelarutan dalam air (Ferone et al., 2013)

Kandungan kation dalam karbon aktif dapat meningkatkan nilai $\mathrm{pH}$ pada air. Kontak yang lama antara karbon aktif tempurung kelapa dan sampel air akan berpengaruh pada kenaikan nilai $\mathrm{pH}$. Pada konsentrasi karbon aktif 0,3 gram bisa menaikkan nilai $\mathrm{pH}$ dari 6,48 menjadi 6,64 dan pada konsentrasi 0,6 gram rata-rata peningkatan $\mathrm{pH}$ menjadi 6,71 sedangkan pada konsentrasi 0,9 gram peningkatan rata-rata nilai $\mathrm{pH}$ menjadi 6,74 (Jamilatun \& Setyawan, 2014). Berikut efisiensi penuruna kadar $\mathrm{Fe}$ dan $\mathrm{Mn}$ pada reaktor filtrasi bermedia karbon aktif setelah melalui proses pada tray aerator yang akan ditujukan pada Tabel 3 dan Tabel 4. 
Tabel 3. Efisiensi Removal Kadar Fe pada Filtrasi Media Karbon Aktif

\begin{tabular}{ccccc}
\hline Hari & Awal (mg/l) & Akhir $(\mathbf{m g} / \mathbf{l})$ & Penurunan $(\mathbf{m g} / \mathbf{l})$ & Efisiensi \\
\hline 1 & 1,68 & $0,294 \times 10^{-2}$ & 1,6506 & $98,25 \%$ \\
2 & 1,68 & $0,292 \times 10^{-2}$ & 1,6508 & $98,26 \%$ \\
3 & 1,68 & $0,291 \times 10^{-2}$ & 1,6509 & $98,26 \%$ \\
4 & 1,68 & $0,289 \times 10^{-2}$ & 1,6511 & $98,27 \%$ \\
5 & 1,68 & $0,260 \times 10^{-2}$ & 1,6540 & $98,45 \%$ \\
6 & 1,68 & $0,255 \times 10^{-2}$ & 1,6545 & $98,48 \%$ \\
7 & 1,68 & $0,253 \times 10^{-2}$ & 1,6547 & $98,48 \%$ \\
\hline
\end{tabular}

Tabel 4. Efisiensi Removal Kadar Mn pada Filtrasi Media Karbon Aktif

\begin{tabular}{ccccc}
\hline Hari & Awal $(\mathbf{m g} / \mathbf{l})$ & Akhir $(\mathbf{m g} / \mathbf{l})$ & Penurunan $(\mathbf{m g} / \mathbf{l})$ & Efisiensi \\
\hline 1 & 1,14 & $0,210 \times 10^{-2}$ & 1,1190 & $98,15 \%$ \\
2 & 1,14 & $0,211 \times 10^{-2}$ & 1,1189 & $98,14 \%$ \\
3 & 1,14 & $0,211 \times 10^{-2}$ & 1,1189 & $98,14 \%$ \\
4 & 1,14 & $0,299 \times 10^{-2}$ & 1,1101 & $97,37 \%$ \\
5 & 1,14 & $0,296 \times 10^{-2}$ & 1,1104 & $97,40 \%$ \\
6 & 1,14 & $0,296 \times 10^{-2}$ & 1,1104 & $97,40 \%$ \\
7 & 1,14 & $0,295 \times 10^{-2}$ & 1,1105 & $98,25 \%$ \\
\hline
\end{tabular}

Berdasarkan tabel 3 efisiensi penurunan kadar Fe dari awal penelitian sampai hari terakhir terus terjadi peningkatan efisiensi penurunan dengan rata-rata penuruna sebesar $98,35 \%$. Efisiensi penurunan terbaik yaitu pada hari ke-7 yaitu mencapai $98,49 \%$. Sedangkan pada tabel 4 nilai efisiensi penurunan kadar Mn dari awal sampai akhir penelitian berkisaran antara 97,40\% sampai 98,25\%. Efisiensi penurunan terbaik yakni pada hari ke7 yang mencapai $98,25 \%$. Semakin kecil aliran air yang dialirkan, maka niali efisiensinya akan semakin besar, begitupun sebaliknya (Oesman $\&$ Sugito, 2017). Terjadinya penurunan Fe dan Mn pada filtrasi bermedia karbon aktif di karenakan pada proses filtrasi terjadi proses pengendapan dan pemisahan polutan hasil aerasi (Purwonugroho, 2013). Karbon aktif pada proses filtrasi berfungsi sebagai adsorben yang dapat mengadsorpsi gas-gas dan senyawa kimia tertentu seperti Fe dan Mn.

Penelitian terdahulu (Mugiyantoro et al., 2017) mampu menurunkan kadar Fe pada preoses filtrasi yaitu mencapai $99 \%$. Tingginya nilai efisiensi yang dihasilkan karena adanya pengkombinasian media filter yang diterapkan dalam satu reactor yaitu media karbon aktif, zeolite dan pasir silika. Pada penerapan media filter dengan ketinggian media $60 \mathrm{~cm}$ mampu menurukan kadar Mn mencapai 72,56\% (Purwonugroho,
2013). Perbedaan ketinggian media akan mempengaruhi hasil akhir dari proses filtrasi itu sendiri. Semakin tinggi permukaan media yang digunakan, maka akan semakin besar efisiensi penyisihan yang dihasilkan. Volume reaktor yang digunakan juga akan mempengaruhi hasil dari suatu pengolahan air. Semakin besar volume reaktornya, maka semakin besar angka penurunan pencemarnya.

\subsection{Efisiensi Removal Kadar Fe dan Mn pada Filtrasi Bermedia Pasir Zeolit}

Batuan zeolite yang diperoleh untuk dijadikan media filter haruslah yang sudah diaktivasi terlebih dahulu agar daya serapnya semakin baik. Media filter zeolite yang digunakan sebelumnya harus memiliki berat yang konstan. Selain digunakan untuk pengolahan air bersih dan air minum, media zeolite juga dapat digunakan sebagai media untuk mengolah air limbah. Penambahan masa zeolit akan berpengaruh pada peningkatan nilai $\mathrm{pH}$, dimana secara drastis nilai $\mathrm{pH}$ akan meningkat dari $\mathrm{pH} 05,08$ menjadi 06.64 pada masa zeolit $600,00 \mathrm{~g}$ (Rahayu et al., 2015). Berikut efisiensi reduksi kadar $\mathrm{Fe}$ dan $\mathrm{Mn}$ pada filtrasi bermedia pasir zeolit setelah melalui proses pada tray aerator akan ditujukan pada Tabel 5 dan 6. 
Tabel 5. Removal Kadar Fe pada Filtrasi Pasir Zeolit

\begin{tabular}{ccccc}
\hline Hari & Awal $(\mathbf{m g} / \mathbf{l})$ & Akhir $(\mathbf{m g} / \mathbf{l})$ & Penurunan $(\mathbf{m g} / \mathbf{l})$ & Efisiensi \\
\hline 1 & 1,68 & $0,280 \times 10^{-2}$ & 1,6520 & $98,33 \%$ \\
2 & 1,68 & $0,270 \times 10^{-2}$ & 1,6530 & $98,39 \%$ \\
3 & 1,68 & $0,265 \times 10^{-2}$ & 1,6535 & $98,42 \%$ \\
4 & 1,68 & $0,263 \times 10^{-2}$ & 1,6537 & $98,43 \%$ \\
5 & 1,68 & $0,290 \times 10^{-2}$ & 1,6510 & $98,27 \%$ \\
6 & 1,68 & $0,290 \times 10^{-2}$ & 1,6510 & $98,27 \%$ \\
7 & 1,68 & $0,297 \times 10^{-2}$ & 1,6503 & $98,23 \%$ \\
\hline
\end{tabular}

Tabel 6. Efisiensi Removal Kadar Mn pada Filtrasi Pasir Zeolit

\begin{tabular}{ccccc}
\hline Hari & Awal $(\mathbf{m g} / \mathbf{l})$ & Akhir $(\mathbf{m g} / \mathbf{l})$ & Penurunan $(\mathbf{m g} / \mathbf{l})$ & Efisiensi \\
\hline 1 & 1,14 & $0,294 \times 10^{-2}$ & 1,1106 & $97,41 \%$ \\
2 & 1,14 & $0,294 \times 10^{-2}$ & 1,1106 & $97,42 \%$ \\
3 & 1,14 & $0,295 \times 10^{-2}$ & 1.1105 & $97,41 \%$ \\
4 & 1,14 & $0,297 \times 10^{-2}$ & 1,1103 & $97,39 \%$ \\
5 & 1,14 & $0,294 \times 10^{-2}$ & 1,1106 & $97,42 \%$ \\
6 & 1,14 & $0,291 \times 10^{-2}$ & 1,1109 & $97,44 \%$ \\
7 & 1,14 & $0,291 \times 10^{-2}$ & 1,1109 & $97,44 \%$ \\
\hline
\end{tabular}

Tabel 5 dan 6 merupakan efisiensi penurunan kadar $\mathrm{Fe}$ dan $\mathrm{Mn}$ pada reaktor filtrasi bermedia pasir zeolite, dimana presentase penurunan untuk kadar Fe dari hari pertama sampai hari terakhir berkisaran antara 98,23\% sampai 98,43\%. Sedangkan untuk kadar Mn berkisaran antara 97,39\% sampai $97,44 \%$. Besarnya nilai penyisihan yang terjadi pada media zeolite untuk kadar Fe dan Mn dikarenakan pada filtrasi bermedia pasir zeolit terjadi reaksi pertukaran ion. Selain itu, rongga-ronga yang terdapat pada pasir zeolit juga menyebabkan pasir zeolit berfungsi sebagai adsorben. Jika dibandingkan dengan penelitian yang dilakukan oleh (Purwonugroho, 2013), maka penelitian ini lebih baik. Efisiensi penurunan kadar $\mathrm{Fe}$ hanya mencapai $94 \%$, sedangkan untuk kadar Mn mencapai 84\%. Perbedaan ketinggian media filter memberikan pengaruh yang besar terhadap nilai efisiensi yang dihasilkan. Penerapan ketinggian media zeolit, pasir halus dan kerikil sebesar $120 \mathrm{~cm}$ menghasilkan nilai efisiensi kadar Mn sebesar $100 \%$ (El-Naggar, 2010). Sedangkan penerapan keringgian media zeolit yang dikombinasikan dengan media pasir halus dan kerikil dengan tinggi media masing-masing $20 \mathrm{~cm}$ mampu menurunkan kadar Mn sebesar 88\% (Siwila et al., 2017).

34

\section{SIMPULAN}

Penerapan teknologi tray aerator dan filtrasi terbilang berhasil karena mampu mereduksi zat Fe dan Mn dalam air. Sistem aerasi tray aerator mampu menurunkan kadar Fe hingga 98,34\%, dan kadar Mn mencapai penurunan sebesar 97,40\%. Sedangkan penerapan filtrasi karbon aktif mampu menurunkan kadar $\mathrm{Fe}$ sebesar 98,48\% sedangkan untuk Mn mencapai 98,25\%. Proses filtrasi menggunakan pasir zeolite mampu menurunkan kadar Fe hingga 98,43\% dan kadar Mn mencapai 97,44\%. Disarankan untuk penelitian lebih lanjut untuk menerapkan waktu kontak yang lebih lama terutama pada bagian filtrasi serta memperbanyak tray aerator sehingga hasilnya lebih maksimal.

\section{DAFTAR PUSTAKA}

Astuti, W., Jumali, A., \& Amin, M. (2007). Desalinasi Air Payau Menggunakan Surfactant Modified Zeolite (SMZ). Jurnal Zeolit Indonesia, 3(2), 32-37. https://doi.org/10.1017/CBO9781107415 324.004 
Azkiyah, I. N. F., \& Sutrisno, J. (2014). Penurunan Kadar Besi (Fe) dan Mangan (Mn) pada Air Sumur Gali dengan Metode Aerasi dan Filtrasi Di Sukodono Sidoarjo. Jurnal Teknik WAKTU, 12(2), 28-33.

Baylar, A., Bagatur, T., \& Emiroglu, M. E. (2007). Aeration efficiency with nappe flow over stepped cascades. Proceedings of the Institution of Civil Engineers Water Management, 160(1), 43-50. https://doi.org/10.1680/wama.2007.160.1 .43

Cobb, A., Warms, M., Maurer, E. P., \& Chiesa, S. (2012). Low-Tech Coconut Shell Activated Charcoal Production. International Journal for Service Learning in Engineering, Humanitarian Engineering and Social Entrepreneurship, 7(1), 93-104. https://doi.org/10.24908/ijsle.v7i1.4244

El-Naggar, H. (2010). Development of low cost technology for the removal of iron and manganese from ground water in Siwa Oasis. The Journal of the Egyptian Public Health Association, 85(3-4), 169-188.

Febiary, I., Fitria, W. A., \& Yuniarno, S. (2016). Efektivitas Aerasi, Sedimentasi, dan Filtrasi untuk Menurunkan Kekeruhan dan Kadar Besi (Fe) dalam Air. Journal of Chemical Information and Modeling, 8(1), 32-39. https://doi.org/10.1017/CBO9781107415 324.004

Ferone, C., Colangelo, F., Roviello, G., Asprone, D., Menna, C., Balsamo, A., Prota, A., Cioffi, R., \& Manfredi, G. (2013). Application-oriented chemical optimization of a metakaolin based geopolymer. Materials, 6(5), 1920-1939. https://doi.org/10.3390/ma6051920

Herlambang, A. (2010). Teknologi Penyediaan Air Minum Untuk Keadaan Tanggap Darurat. Jai, 6(1), 52-63.

Jamilatun, S., \& Setyawan, M. (2014). Pembuatan Arang Aktif dari Tempurung Kelapa dan Aplikasinya untuk Penjernihan Asap Cair. Spektrum
Industri, 12(1), 73-83.

Joko, T., \& Rachmawati, S. (2016). Variasi Penambahan Media Adsorpsi Kontak Aerasi Sistem Nampan Bersusun (Tray Aerator) Terhadap Kadar Besi (Fe) Air Tanah Dangkal di Kabupaten Rembang. 15(1), 1-5.

Lutfihani, A., \& Purnomo, A. (2015). Analisis Penurunan Kadar Besi (Fe) dengan Menggunakan Tray aerator dan Diffuser Aerator. 4(1), 25-27.

Mifbakhuddin, Wardani, R. S., \& Rozaq, A. P. (2008). Pengaruh Ketebalan Diameter Zeolit Digunakan Sebagai Media Filter Terhadap Penurunan Kesadahan Air Sumur Artetis di Kelurahan Sendangguwo Kecamatan Tembalang Kota Semarang. Jurnal Kesehatan Masyarakat Indonesia , 4(2), 51-69.

Mugiyantoro, A., Husna Rekinagara, I., Dian Primaristi, C., \& Soesilo, J. (2017). Penggunaan Bahan Alam Zeolit, Pasir Silika, Dan Arang Aktif Dengan Kombinasi Teknik Shower Dalam Filterisasi Fe, Mn, Dan Mg Pada Air Tanah Di Upn "Veteran" Yogyakarta. Seminar Nasional Kebumian Ke-10, 492, 1127-1137.

Muliawan, A., \& Ilmianih, R. (2016). Metoda Pengurangan Zat Besi Dan Mangan Menggunakan Filter Bertingkat Dengan Penambahan UV Sterilizer Skala Rumah Tangga. Jurnal Ilmiah Giga, 19(1), 1-8. http://journal.unas.ac.id/giga/article/view 1298

Nainggolan, A., Tarigan, A., \& Khair, H. (2017). Pengaruh Aerasi Bertingkat dengan Kombinasi Saringan Pasir, Karbon Aktif, dan Zeolit dalam Menyisihkan Parameter Fe dan Mn dari Air Tanah di Pesantren Ar-Raudhatul Hasanah. Jurnal Dampak, 14, 1. https://doi.org/10.25077/dampak.14.1.112.2017

Nurhasmi, Subaer, \& Nurhayati. (2015). Pengembangan Geopolimer Berbasis Karbon Aktif sebagai Keramik Filter Ganda (Double Filter) untuk Aplikasi Pengolahan Air Sumur. 11(3), 280-285. 
https://ojs.unm.ac.id/index.php/JSdPF/art icle/view/1753

Oesman, N. M., \& Sugito. (2017). Penurunan Logam Besi dan Mangan Menggunakan Filtrasi Media Zeolit dan Manganese Greensand. Jurnal Teknik WAKTU, 15(2), 57-65.

Purwono, \& Karbito. (2013). Pengolahan Air Sumur Gali Menggunakan Saringan Pasir Bertekanan (Presure Sand Filter) untuk Menurunkan Kadar Besi (Fe) dan Mangan (Mn)(Studi Kasus di Desa Banjar Negoro Kecamatan Wonosobo Tanggamus). Jurnal Kesehatan Lingkungan Poltekkes Kemenkes Tanjungkarang, 4(1), 305-314.

Purwonugroho, N. (2013). Keefektifan Kombinasi Media Zeolit dan Karbon Aktif. In Universitas Muhammadiyah Surakarta. Universitas Muhammadiyah Surakarta.

Rahayu, A., Masturi, M., \& Yulianti, I. (2015). Pengaruh Perubahan Massa Zeolit Terhadap Kadar $\mathrm{Ph}$ Limbah Pabrik Gula Melalui Media Filtrasi. Jurnal Fisika (Semarang), 5(2), 1-4. https://doi.org/10.15294/jf.v5i2.7411

Rasman, R., \& Saleh, M. (2016). Penurunan Kadar Besi (Fe) Dengan Sistem Aerasi dan Filtrasi Pada Air Sumur Gali (Eksperimen). HIGIENE: Jurnal Kesehatan Lingkungan, 2(3), 159-167. http://journal.uinalauddin.ac.id/index.php/higiene/article/ view/1826

Rezagama, A. (2013). Studi Ozonisasi Senyawa Organik Air Lindi Tempat Pemrosesan Akhir Sarimukti. Teknik, 34(2), 82. https://doi.org/10.14710/teknik.v34i2.56 30

Ronny, \& Hasim, A. H. (2018). Effectiveness of multiple tray-aerators in reducing iron (Fe) water wells in Gowa Regency, Indonesia. Ecology, Environment and Conservation, 24(1), 22-25. https://doi.org/10.31227/osf.io/yqv8j
Saifudin, M. R., \& Astuti, D. (2005). Kombinasi Media Filter untuk Menurunkan Kadar Besi (Fe). Penelitian Sains Dan Teknologi, 6(1), 49-64. http://hdl.handle.net/11617/376

Siwila, S., Chota, C., Yambani, K., Sampa, D., Siangalichi, A., Ndawa, N., \& Tambwe, G. (2017). Design of a small scale iron and manganese removal system for Copperbelt University's borehole water. Journal of Environmental Geology, 01(01), 24-30. https://doi.org/10.4172/25917641.1000007

Wahyudin, Tjahjanto, R. T., \& Wardhani, S. (2013). Kombinasi Ozonisasi, Iradiasi Ultraviolet Dan Zeolit Untuk Disinfeksi Air Tanah Dan Penentuan Konsentrasi Ozon Dengan Metode Spektrofotometri Uv-Visible. Jurnal Student Kimia, 1(1), 126-132. 